\title{
Progesterone supplementation postinsemination improves fertility of cooled dairy cows during the summer
}

\author{
E. Friedman, ${ }^{\star} Z$. Roth,${ }^{*}$ H. Voet, $\nmid$ Y. Lavon,‡ and D. Wolfenson ${ }^{\star 1}$ \\ *Department of Animal Sciences, and \\ †Department of Agricultural Economics and Management, Faculty of Agriculture, Food and Environment, the Hebrew University, \\ Rehovot 76100, Israel \\ łlsrael Cattle Breeders Association, Caesarea 38900, Israel
}

\begin{abstract}
Reduced fertility of dairy cows during periods of elevated temperature, humidity, or both might be associated with low plasma progesterone concentration. Alleviation of thermal stress by efficient cooling is a prerequisite for improving fertility by hormonal treatment. We examined whether insertion of a controlled intravaginal drug-releasing (CIDR) insert containing progesterone following artificial insemination (AI) would improve summer conception rate. Control (n $=195)$ and treated (CIDR; $\mathrm{n}=165)$ cows, yielding on average $42.3 \mathrm{~kg}$ milk/d, were inseminated following estrus detection during the summer (July to October) in 2 commercial dairy herds in Israel. Mean maximal air temperature and relative humidity during the study were $30.2^{\circ} \mathrm{C}$ and $86 \%$, respectively. All experimental cows were efficiently cooled throughout the study, as confirmed by measuring the body temperature of random cows. Treated cows received a CIDR insert on $\mathrm{d} 5$ \pm 1 post-AI for $13 \mathrm{~d}$ and pregnancy was confirmed by palpation $45 \mathrm{~d}$ post-AI. Plasma progesterone concentration in treated cows was elevated by approximately $1.5 \mathrm{ng} / \mathrm{mL}$. Multiple logistic regressions were used to analyze conception rate. Treatment did not alter the overall conception rate; however, probability of conception increased in CIDR-treated cows with low body condition score (BCS) compared with their control counterparts (53 vs. $27 \%$, respectively). A pronounced increase in probability of conception was recorded in CIDR-treated cows exhibiting both low BCS and postpartum reproductive disorders, compared with their control counterparts (58 vs. 14\%, respectively). Exogenous progesterone supplementation on d 5 post-AI for $13 \mathrm{~d}$ improves summer fertility of subpopulations of cows exhibiting low BCS and postpartum reproductive disorders. Reproductive management based on specific hormonal treatment of designated subgroups of cows
\end{abstract}

Received October 4, 2011.

Accepted February 8, 2012

${ }^{1}$ Corresponding author: wolf@agri.huji.ac.il known to derive beneficial effects from it might improve treatment efficiency and reduce expenses.

Key words: cooling, fertility, summer, progesterone

\section{INTRODUCTION}

Plasma progesterone $\left(\mathbf{P}_{4}\right)$ concentrations are lower in cows during summer than during spring (Howell et al., 1994) or winter (Jonsson et al., 1997; Wolfenson et al., 2002). However, plasma $\mathrm{P}_{4}$ concentrations have been reported to be greater (Trout et al., 1998; Wilson et al., 1998) or similar (Roth et al., 2000) in cows under acute heat stress compared with those under normothermic conditions. An in vitro study has shown decreased production of $\mathrm{P}_{4}$ by follicular cells collected and luteinized during the summer compared with winter. This reduction in $\mathrm{P}_{4}$ production is mostly attributed to effects of heat exposure on theca-derived luteal cells (Wolfenson et al., 2002). Taken together, it seems that chronic seasonal exposure has a deleterious carry-over effect on follicular function that leads to the formation of a suboptimal corpus luteum (CL) and, subsequently, to low $\mathrm{P}_{4}$ concentration in the plasma (Wolfenson et al., 2000).

Poor embryonic development and IFN- $\tau$ production are associated with impaired luteal function, reflected by a delayed postovulatory increase in $\mathrm{P}_{4}$ concentrations and low $\mathrm{P}_{4}$ concentrations in the luteal phase (Mann and Lamming, 2001). In turn, embryo production of sufficient quantities of IFN- $\tau$ by d 16 is required to prevent endometrial secretion of prostaglandins and subsequent luteolysis (Mann et al., 1999). Another study showed that $\mathrm{P}_{4}$ concentrations as early as $\mathrm{d} 5$ postestrus are positively associated with embryonic development (Green et al., 2005). Larson et al. (1997) showed that milk $\mathrm{P}_{4}$ concentration was greater beginning d 4.5 postinsemination in pregnant versus nonpregnant cows. In agreement, $\mathrm{P}_{4}$ supplementation during the early (d 5 to 9 ) but not late (d 12 to 16) luteal phase increased trophoblast length and IFN- $\tau$ production on d 16 postfertilization (Mann et al., 2006). Taken together, $\mathrm{P}_{4}$-induced changes in endometrial secretions 
are essential for blastocyst survival and development (Spencer et al., 2008). Thus, altering luteal function and reduced $\mathrm{P}_{4}$ concentration in the circulation under thermal stress might impair embryonic development and increase early embryonic loss.

Studies attempting to moderate the deleterious effects of heat stress on luteal function by inducing an accessory CL and excess luteal tissue have yielded equivocal results. Administration of GnRH between d 5 and 15 post-AI was reported to increase conception rate (CR) by approximately 15 percentage units (Willard et al., 2003; López-Gatius et al., 2006), whereas others found no improvement in summer fertility (Franco et al., 2006). Similarly, administering human chorionic gonadotropin (hCG) on d 5 or 6 post-AI did not affect (Schmitt et al., 1996) or increased CR by 13 percentage units (Beltran and Vasconcelos, 2008). Variations in the day of hCG or GnRH administration might explain the discrepancies in CR among studies, presumably because of temporal differences in the increase in $\mathrm{P}_{4}$ production and its subsequent increased concentration in the plasma. Differences among studies could also be related to the severity and duration of the thermal stress to which the cows were exposed and, most importantly, to the efficiency of the cooling strategies used and their ability to maintain normothermia.

We hypothesized that elevation of circulating $\mathrm{P}_{4}$ concentrations during very early stages of pregnancy would improve conception of cows during the summer. Specifically, the objective was to examine whether insertion of a controlled intravaginal drug-releasing (CIDR) insert containing $\mathrm{P}_{4}$ on $\mathrm{d} 5$ post-AI (for $13 \mathrm{~d}$ ) would improve fertility in dairy cows during the summer. Using this method, the induced elevation in $\mathrm{P}_{4}$ concentration coincided with the early luteal phase. As cooling is an essential management practice commonly and widely used in most warm, developed counties, the study was carried out on dairy farms equipped with efficient cooling systems. Data were analyzed in relation to potential risk factors associated with reduced fertility, including BCS, parity, postpartum reproductive disorders, milk yield, and SCC.

\section{MATERIALS AND METHODS}

\section{Animals and Data Collection}

The study was conducted in 2 commercial dairy herds located in the coastal plain of Israel in accordance with the guidelines of the ethics committee of the Hebrew University. Holstein cows inseminated between July and October in 2 consecutive years were included in the study. Cows were housed in open sheds, had access to open concrete yards, were milked 3 times daily, and were fed a TMR containing $1.7 \mathrm{Mcal}$ of $\mathrm{NE}_{\mathrm{L}} / \mathrm{kg}$ of $\mathrm{DM}$, $16.5 \%$ protein, and $32 \%$ NDF. All cows were subjected to similar routine veterinary health management and were diagnosed and treated for postpartum diseases on d 5 to 12 postpartum. Retained placenta was defined as the presence of fetal membranes $24 \mathrm{~h}$ after calving. Metritis was diagnosed according to type of vaginal discharge, and uterine tone and consistency were evaluated by palpation per rectum. Cows with retained placenta or metritis were defined as having postpartum reproductive disorder and were treated with intrauterine antibiotics until disappearance of clinical signs. Body condition score was evaluated by the veterinarian on a 5-point scale (Wildman et al., 1982) after parturition and at peak lactation (i.e., 50 to 60 DIM). Estrous behavior was recorded by computerized pedometric system (SAE, Afikim, Israel) and by visual observation. Milk production was recorded monthly, and SCC was analyzed by the Central Laboratory for Milk Recording of the Israeli Cattle Breeding Association. The milking records before and after AI were used for data analysis.

\section{Cooling Management and Temperature Measurements}

Cooling management was based on 24-h ventilation of the open sheds and cooling windows, lasting 30 to $60 \mathrm{~min}$, of frequent intermittent use of fans and sprinklers in the parlor before milking (holding area) and along the feeding lines (Berman and Wolfenson, 1992). All cows in this study were cooled in the holding area 3 times a day before milking and were moved to the holding area to be cooled twice more between milkings. Cooling was operated along the feeding lines when the cows returned from milking and after feed distribution. Overall, cows were exposed to the above-described cooling windows for an average of 6 to $7 \mathrm{~h} / \mathrm{d}$.

Records of environmental temperature and relative humidity were taken from a station located within 20 $\mathrm{km}$ of the farms. In addition, a portable device (model number 45158, Extech Instruments Corp., Waltham, MA) was used to record air temperature and relative humidity on the farm. To evaluate the effectiveness of cooling management and whether cows maintained normothermia, rectal temperatures of random cows (10 to 15 cows per point of measurement) were taken on a representative summer day using a digital thermometer (Toshiba, Tokyo, Japan).

\section{Experimental Protocol}

Lactating cows ( $<200$ DIM) at first to third AI were assigned randomly to a control or CIDR treatment. Artificial insemination was carried out for all experi- 
mental cows by a professional technician from the local AI services after detection of estrus. Cows were inseminated once a day in the morning hours on day of estrus (d 0) or on d 1 if estrus was manifested after noon on $\mathrm{d}$ 0. Cows treated with a CIDR received an insert containing $1.9 \mathrm{~g}$ of $\mathrm{P}_{4}$ (Eazi-Breed CIDR Cattle Insert, Pfizer Animal Health, New York, NY) on d $5 \pm 1$ postAI, and all inserts were removed after $13 \mathrm{~d}$. Pregnancy diagnosis was performed by palpation per rectum at 40 to $50 \mathrm{~d}$ post-AI. Cows that were presented for AI more than once during the experimental period were assigned randomly to treatment or control on each occasion and analyzed as 2 different experimental units. To prevent a possible carry-over effect of the previous CIDR administration, treated cows that returned to estrus and were reinseminated within $10 \mathrm{~d}$ of CIDR removal (on d 18 to 28 after initial estrus) were excluded from the data analysis.

\section{Plasma Hormones}

A subset of control and treated cows was selected randomly for blood sampling. Samples were collected via the coccygeal vessel on $\mathrm{d} 1,5,9,12,16$, and 19 post-AI, and plasma was stored at $-20^{\circ} \mathrm{C}$ until analysis. Progesterone concentrations were quantified by using a solid-phase RIA kit (Diagnostic Product Corp., Los Angeles, CA) against a standard curve prepared with ovariectomized cow plasma as described previously (Shaham-Albalancy et al., 2000).

\section{Statistical Analysis}

Number of AI, days from calving to AI, and milk yield were analyzed by one-way ANOVA using JMP version 7.0 (SAS Institute Inc., Cary, NC). Plasma $\mathrm{P}_{4}$ concentration was analyzed by 2-way ANOVA with repeated measures. The model included treatment, day post-AI, and day $\times$ treatment interaction. Data are presented as means \pm standard errors of the means.

Multiple logistic regression (SAS version 9.1, SAS Institute Inc.) was used to model the probability of overall conception (first to third AI). The following variables were considered in a backward stepwise procedure: farm, year, parity (primiparous vs. multiparous), number of AI (first vs. second or third), BCS at calving (cutoff at $\leq 2.75$ ), BCS at peak lactation (cutoff at $\leq 2.25$ ), change in BCS between calving and peak lactation (cutoff at $\geq 0.75$ ), milk yield (cutoff at $>40$ $\mathrm{kg} / \mathrm{d}$ ), season of AI [early summer (July and August) vs. late summer (September and October)], postpartum reproductive disorders, SCC (cutoff at $>150,000$ cells/ $\mathrm{mL}$ ), interval between calving and AI (cutoff at $\leq 120$ d), and their interactions with treatment. Variables included in the final model and presented were those passing the retention criteria set at $P<0.15$ and the associated main effects. Interactions with $P>0.15$ in the final model were removed in a single pass to focus on the more relevant effects. The same variables and retention criteria were used to model the probability of conception at first AI. Interaction between low BCS at peak lactation and postpartum reproductive disorders (LBCS-RD) was used with the same variables and the same retention criteria for an additional analysis to model the probability of overall conception.

\section{RESULTS}

Overall, 183 multiparous and 100 primiparous cows were included in the study, with a total of 360 inseminations (210, 99, and 51 for first, second, and third AI, respectively). Of these, 165 cows were treated with CIDR inserts and 195 served as controls. Average number of pretreatment AI did not differ between control and CIDR cows $(1.6 \pm 0.05$ and $1.5 \pm 0.06$, respectively). Days from calving to first AI $(110 \pm 2.6$ and $108 \pm 2.4 \mathrm{~d})$ and to all AI $(127 \pm 2.3$ and $123 \pm 2.5 \mathrm{~d})$ did not differ between control and CIDR-treated cows, respectively. Average milk yield at AI did not differ between experimental groups: $42.2 \pm 0.6$ and $42.5 \pm 0.7$ $\mathrm{kg} / \mathrm{d}$ for control and CIDR-treated cows, respectively.

\section{Environmental Temperature, Body Temperature, and Plasma Progesterone}

Mean minimal and maximal air temperature and relative humidity were 21.5 and $31.2^{\circ} \mathrm{C}, 48$ and $89 \%$, respectively, during early summer, and 19.8 and $29.2^{\circ} \mathrm{C}$, 47 and $84 \%$, respectively, in late summer. The average rectal temperature measurements for cows on farms A and $\mathrm{B}$ were $38.9 \pm 0.1$ and $38.8 \pm 0.1^{\circ} \mathrm{C}$, respectively. Air temperature and relative humidity at the time of rectal temperature measurement were, respectively, 30.1 $\pm 0.4^{\circ} \mathrm{C}$ and $56.2 \pm 2.2 \%$ (farm A) and $29.3 \pm 0.4^{\circ} \mathrm{C}$ and $52.5 \pm 1.8 \%$ (farm $\mathrm{B}$ ). Mean rectal temperatures during the afternoon and evening hours ranged between 38.4 and $39.6^{\circ} \mathrm{C}$, and decreases in body temperature were associated with cooling sessions in the holding area (Figure 1). Analysis of plasma $\mathrm{P}_{4}$ concentration revealed a day by treatment interaction $(P<0.06)$, with approximately $1.5 \mathrm{ng} / \mathrm{mL}$ greater $\mathrm{P}_{4}$ concentration in the treated cows from d 9 to 16 of the cycle.

\section{Conception Rate}

Overall CR was 33 and $42 \%$ for control and treatment, respectively, and did not differ between treatments. Logistic regression to model overall CR is pre- 


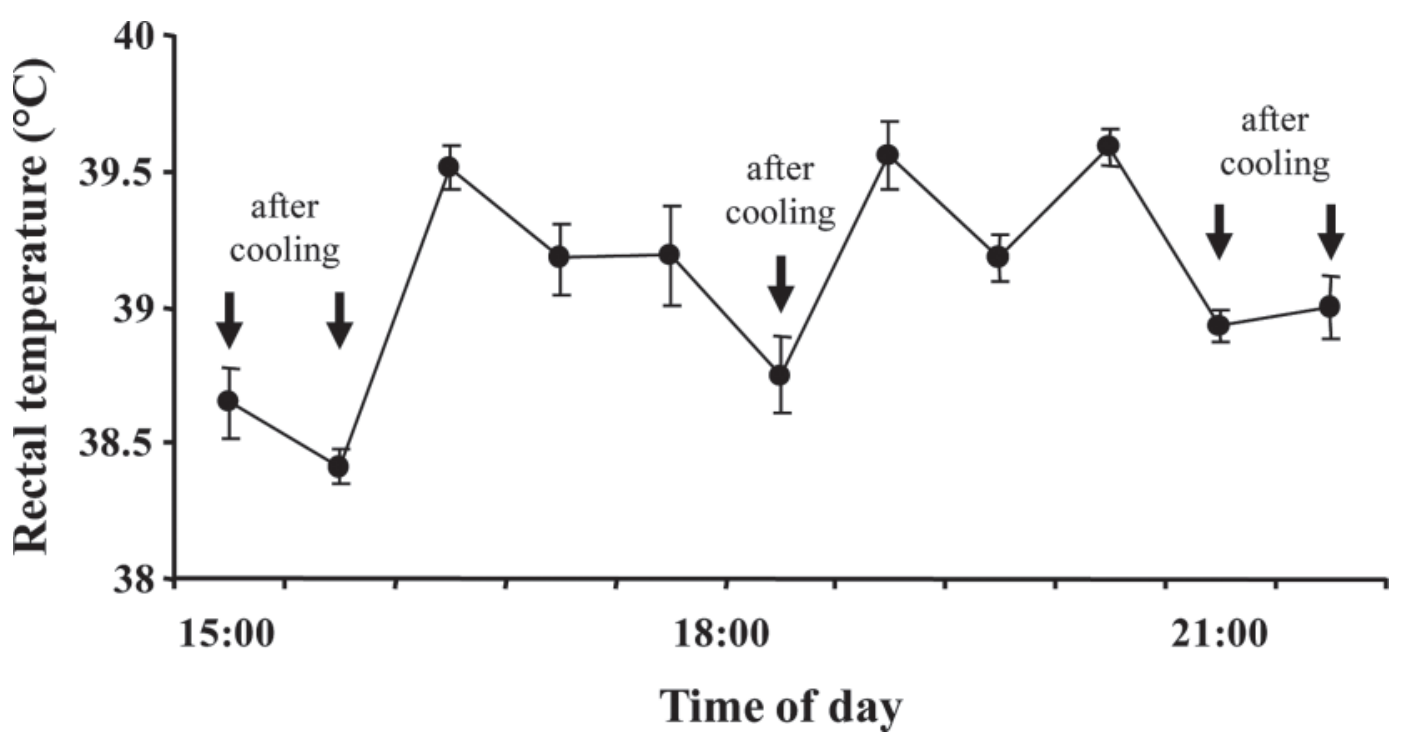

Figure 1. Measurements of body temperature from randomly selected cows ( $\mathrm{n}=10$ to 15 cows per measurement) on a representative summer day on farm A. Arrows indicate when measurements were made in cows after exposure to cooling periods.

sented in Table 1. The analysis revealed an interaction $(P=0.035)$ between treatment and low BCS at peak lactation, reflected by a 26-percentage-unit increase in $\mathrm{CR}$ of treated cows with low BCS relative to their control counterparts. At first AI, CR was greater $(P=$ $0.031)$, as reflected by a 14-percentage-unit increase, compared with that at second and third AI. Cows with high SCC showed a 13-percentage-unit decrease in CR $(P=0.028$; Table 1$)$, with no interaction with CIDR treatment. Similarly, cows in farm A tended to show a 12-percentage unit-decrease in $\mathrm{CR}(P=0.066)$ compared with cows in farm $\mathrm{B}$, with no interaction with CIDR treatment.

Postpartum reproductive disorders did not interact with CIDR treatment $(P=0.128)$; however, a 23-percentage-unit increase in CR was noted in the treated cows diagnosed with postpartum reproductive disease relative to their control counterparts (Table 1). To further examine the effect of CIDR treatment on cows with postpartum reproductive disorders, we determined the overall probability of conception of the LBCS-RD subgroup (Table 2). The LBCS-RD status decreased the probability of conception $(P=0.013)$, although actual CR were similar to those of healthy cows with high BCS due to inclusion of CIDR-treated cows in those subgroups. Accordingly, treatment with CIDR interacted with LBCS-RD cows to increase the probability of conception $(P=0.005$; Table 2$)$, reflected by a 44-percentage-unit increase in $\mathrm{CR}$ of the treated LBCS-RD cows compared with their control counterparts.
Logistic regression to model first AI CR is presented in Table 3. Low BCS at peak lactation interacted with CIDR $(P=0.021$; Table 3$)$, reflected by a 32 -percentage-unit increase in first AI CR in treated cows with low BCS relative to their control counterparts. Unlike overall CR (Table 1), the probability of conceiving from first $\mathrm{AI}$ increased $(P=0.037$, Table 3$)$ in late summer (September and October) relative to early summer (July and August); however, we observed no interaction between month of AI (early and late summer) and CIDR treatment. High SCC also entered the latter model as a main effect with no interaction with CIDR treatment, decreasing the probability of conceiving from first $\mathrm{AI}$, as reflected by an 18-percentage-unit decrease in $\mathrm{CR}(P=0.034$; Table 3$)$.

\section{DISCUSSION}

One of the most common strategies used to alleviate the effect of heat stress in dairy farms is based on spraying water to wet the skin and then facilitating its evaporation by forced ventilation. This approach reduces body temperature and increases milk production. Its effect on summer fertility, however, is limited. Here, we report on the potential of $\mathrm{P}_{4}$ supplementation to improve the reproductive performance of intensively cooled cows during the hot season. Administration of a CIDR insert on d 5 post-AI had a substantial effect on the fertility of subpopulations of cows, particularly those with low BCS or diagnosed with postpartum reproductive disorders or both. The current study is 
Table 1. Effect of treatment with a controlled intravaginal drug-releasing (CIDR) insert containing progesterone on conception rate $(\mathrm{CR})$ of first to third AI during summer

\begin{tabular}{|c|c|c|c|c|}
\hline Variable & $\begin{array}{c}\text { Actual CR } \\
{[\% \text { (no./no.) }]}\end{array}$ & $\begin{array}{l}\text { Adjusted } \\
\text { odds ratio }\end{array}$ & $95 \% \mathrm{CI}$ & $P$-value \\
\hline $\mathrm{CIDR}^{1}$ & $42(69 / 165)$ & 0.83 & $(0.41,1.65)$ & 0.588 \\
\hline Control & $33(65 / 195)$ & Referent & & \\
\hline \multicolumn{5}{|l|}{ Farm and year } \\
\hline Farm A - year 1 & $28(15 / 53)$ & 0.52 & $(0.25,1.05)$ & 0.066 \\
\hline Farm A - year 2 & $34(26 / 77)$ & 0.79 & $(0.42,1.47)$ & 0.453 \\
\hline Farm B - year 2 & $40(93 / 230)$ & Referent & & \\
\hline \multicolumn{5}{|l|}{ Number of AI } \\
\hline 1 & $43(90 / 210)$ & 1.68 & $(1.05,2.70)$ & 0.031 \\
\hline 2 and 3 & $29(44 / 150)$ & Referent & & \\
\hline \multicolumn{5}{|l|}{ Month of AI } \\
\hline September and October & $41(65 / 157)$ & 1.30 & $(0.83,2.06)$ & 0.253 \\
\hline July and August & $34(69 / 203)$ & Referent & & \\
\hline \multicolumn{5}{|l|}{ Parity } \\
\hline Primiparous & $42(53 / 127)$ & 1.49 & $(0.65,3.41)$ & 0.342 \\
\hline Multiparous & $35(81 / 233)$ & Referent & & \\
\hline Primiparous $\times$ CIDR & $44(25 / 57)$ & 0.70 & $(0.27,1.84)$ & 0.472 \\
\hline Primiparous $\times$ Control & $40(28 / 70)$ & Referent & & \\
\hline \multicolumn{5}{|l|}{$\mathrm{BCS}^{2}$} \\
\hline Low & $40(52 / 129)$ & 0.71 & $(0.36,1.44)$ & 0.346 \\
\hline High & $35(82 / 231)$ & Referent & & \\
\hline Low $\times$ CIDR & $53(35 / 66)$ & 2.83 & $(1.08,7.41)$ & 0.035 \\
\hline Low $\times$ Control & $27(17 / 63)$ & Referent & & \\
\hline \multicolumn{5}{|l|}{ Reproductive disorders } \\
\hline Diagnosed & $35(41 / 117)$ & 0.48 & $(0.24,0.97)$ & 0.040 \\
\hline Healthy & $38(93 / 243)$ & Referent & & \\
\hline Diagnosed $\times$ CIDR & $48(24 / 50)$ & 2.20 & $(0.80,6.07)$ & 0.128 \\
\hline Diagnosed $\times$ Control & $25(17 / 67)$ & Referent & & \\
\hline \multicolumn{5}{|l|}{$\mathrm{SCC}^{3}$} \\
\hline$>150,000$ cells $/ \mathrm{mL}$ & $28(27 / 97)$ & 0.55 & $(0.32,0.94)$ & 0.028 \\
\hline$<150,000$ cells $/ \mathrm{mL}$ & $41(107 / 263)$ & Referent & & \\
\hline \multicolumn{5}{|l|}{ Milk production ${ }^{3}$} \\
\hline$<40 \mathrm{~kg} / \mathrm{d}$ & $39(63 / 163)$ & 1.20 & $(0.63,2.32)$ & 0.579 \\
\hline$>40 \mathrm{~kg} / \mathrm{d}$ & $36(71 / 197)$ & Referent & & \\
\hline
\end{tabular}

${ }^{1}$ Treated cows received the CIDR insert $5 \pm 1 \mathrm{~d}$ after AI for $13 \mathrm{~d}$.

${ }^{2} \mathrm{BCS} \leq 2.25$ at peak lactation was defined as low.

${ }^{3}$ According to monthly milking records before and after AI.

the first to show an improvement in summer fertility by exogenous $\mathrm{P}_{4}$ supplementation rather than $\mathrm{hCG}$ or $\mathrm{GnRH}$ administration post-AI; the latter are both known to be associated with ovulation of accessory CL and an increase in $\mathrm{P}_{4}$ concentration in the circulation (Schmitt et al., 1996).
Cooling per se was not examined in the current study. It was considered an essential management practice for improving fertility by hormonal means to prevent exposure of the developing embryo to severe hyperthermia. The intensive cooling used here maintained all experimental cows under normothermic to temporary mild

Table 2. Effect of treatment with a controlled intravaginal drug-releasing (CIDR) insert containing progesterone on conception rate $(\mathrm{CR})$ of cows with low $\mathrm{BCS}^{1}$ and postpartum reproductive disorders (LBCS-RD) during summer

\begin{tabular}{|c|c|c|c|c|}
\hline Variable $^{2}$ & $\begin{array}{c}\text { Actual CR } \\
{[\% \text { (no./no.) }]}\end{array}$ & $\begin{array}{c}\text { Adjusted } \\
\text { odds ratio }\end{array}$ & $95 \%$ CI & $P$-value \\
\hline LBCS-RD & $35(19 / 55)$ & 0.24 & $(0.08,0.74)$ & 0.013 \\
\hline High BCS $\times$ Healthy & $36(60 / 169)$ & Referent & & \\
\hline LBCS-RD $\times \mathrm{CIDR}^{3}$ & $58(15 / 26)$ & 7.70 & $(1.84,32.30)$ & 0.005 \\
\hline LBCS-RD $\times$ Control & $14(4 / 29)$ & Referent & & \\
\hline
\end{tabular}

${ }^{1} \mathrm{BCS} \leq 2.25$ at peak lactation was defined as low.

${ }^{2} \mathrm{SCC}$, parity, month and number of AI, farm, year, milk production, and interactions with CIDR treatment affected probability of conception in this data subset as in the full data set (Table 1) and are not presented here.

${ }^{3}$ Treated cows received the CIDR insert $5 \pm 1 \mathrm{~d}$ after $\mathrm{AI}$ for $13 \mathrm{~d}$. 
Table 3. Effect of treatment with a controlled intravaginal drug-releasing (CIDR) insert containing progesterone on first $\mathrm{AI}$ conception rate $(\mathrm{CR})$ during summer

\begin{tabular}{|c|c|c|c|c|}
\hline Variable & $\begin{array}{c}\text { Actual CR } \\
{[\% \text { (no./no.) }]}\end{array}$ & $\begin{array}{l}\text { Adjusted } \\
\text { odds ratio }\end{array}$ & $95 \%$ CI & $P$-value \\
\hline $\mathrm{CIDR}^{1}$ & $50(50 / 101)$ & 0.92 & $(0.44,1.90)$ & 0.813 \\
\hline Control & $37(40 / 109)$ & Referent & & \\
\hline \multicolumn{5}{|l|}{ Month of AI } \\
\hline September and October & $50(51 / 103)$ & 1.85 & $(1.04,3.30)$ & 0.037 \\
\hline July and August & $36(39 / 108)$ & Referent & & \\
\hline \multicolumn{5}{|l|}{ BCS } \\
\hline \multicolumn{5}{|l|}{ Calving $^{2}$} \\
\hline Low & $38(29 / 77)$ & 0.66 & $(0.34,1.28)$ & 0.219 \\
\hline High & $46(58 / 125)$ & Referent & & \\
\hline \multicolumn{5}{|l|}{ Peak lactation ${ }^{3}$} \\
\hline Low & $46(36 / 79)$ & 0.64 & $(0.25,1.61)$ & 0.341 \\
\hline High & $41(54 / 131)$ & Referent & & \\
\hline Low $\times$ CIDR & $59(27 / 46)$ & 4.32 & $(1.25,14.90)$ & 0.021 \\
\hline Low $\times$ Control & $27(9 / 33)$ & Referent & & \\
\hline \multicolumn{5}{|l|}{$\mathrm{SCC}^{4} \times \operatorname{lom}^{2}$} \\
\hline$>150,000$ cells $/ \mathrm{mL}$ & $30(17 / 57)$ & 0.48 & $(0.24,0.95)$ & 0.034 \\
\hline$<150,000$ cells $/ \mathrm{mL}$ & $48(73 / 153)$ & Referent & & \\
\hline
\end{tabular}

hyperthermic conditions. Even when mild hyperthermia was evident (during p.m. hours), body temperature did not exceed $39.6^{\circ} \mathrm{C}$ and most likely was not associated with embryonic death. Several studies have established the importance of cooling during the summer. For instance, Rivera and Hansen (2001) showed that exposing in vitro-derived 2-cell-stage embryos to severe heat shock $\left(41^{\circ} \mathrm{C}\right)$, but not moderate heat shock $\left(40^{\circ} \mathrm{C}\right)$, reduces the proportion of cleaved embryos that develop to the blastocyst stage, indicating that preimplantation embryos can cope with moderate hyperthermia. Jordan (2003) suggested that the degree of hyperthermia underlies differences in efficiency of treatments that induce an accessory CL. In agreement, treatment with hCG or GnRH 5 d post-AI did not improve CR of cows with severe hyperthermia $\left(>39.7^{\circ} \mathrm{C}\right)$ but was found to improve $\mathrm{CR}$ of cows with moderate hyperthermia ( $\leq 39.6^{\circ} \mathrm{C}$; Beltran and Vasconcelos, 2008).

The most important result of the present study was that CIDR treatment improves summer fertility of cows with low BCS (determined at peak lactation). Numerous reports have linked low or decreasing BCS and low $\mathrm{P}_{4}$ concentrations: cows with low BCS at AI tended to have lower plasma $\mathrm{P}_{4}$ concentrations on $\mathrm{d} 11$ to 16 after AI (Santos et al., 2001); the proportion of cows with low $\mathrm{P}_{4}$ at 37 and 58 DIM increased as BCS decreased (Bicalho et al., 2007); and a positive linear relationship was observed on d 65 postpartum between $\mathrm{P}_{4}$ concentration and BCS (Burke et al., 1996). The duration and magnitude of negative energy balance after parturition may attenuate the rate of $\mathrm{P}_{4}$ increase during the first 3 estrous cycles postpartum in cows with severe negative energy balance (Butler, 2000). In this respect, an experiment examining 2 different diets with the same liver blood flow showed a positive correlation between energy balance and the half life of $\mathrm{P}_{4}$ (Lemley et al., 2010). Given the strong association between $\mathrm{BCS}$ and $\mathrm{P}_{4}$ concentrations, it is reasonable to surmise that CIDR counteracted the combined attenuating effects of low BCS and summer heat stress on $\mathrm{P}_{4}$ secretion, resulting in improved CR. Possible mechanisms for reduced $\mathrm{P}_{4}$ concentrations in low BCS cows might include lower $\mathrm{P}_{4}$ production and greater clearance rate of the hormone (Butler, 2000). Low BCS is correlated with lower concentrations of metabolic hormones such as insulin and IGF-I, which have been shown to have an effect on reproduction (Zulu et al., 2002; Diskin et al., 2003). Feed restriction in beef cattle leading to reduced BCS was associated with a smaller $\mathrm{CL}$ and lower concentrations of $\mathrm{P}_{4}$ and IGF-I (Burns et al., 1997). Decreased insulin concentration may be associated with increased activity of liver enzymes contributing to $\mathrm{P}_{4}$ inactivation, thus resulting in a higher metabolic clearance rate of the latter (Lemley et al., 2010). Taken together, these findings might explain, in part, the pronounced increase in summer CR by CIDR treatment in the subpopulation of cows with low BCS.

A marked and significant improvement in $\mathrm{CR}$ was recorded in CIDR-treated cows that exhibited both postpartum reproductive disorders and low BCS (LBCS-RD). The mechanisms underlying this improvement are not clear. It is well known that postpartum 
uterine diseases have a negative effect on fertility of lactating cows (Fourichon et al., 2000). Postpartum reproductive disorders can affect secretion of $\mathrm{PGF}_{2 \alpha}$ or prostaglandin $\mathrm{E}_{2}$ by the endometrium (Mateus et al., 2003; Sheldon et al., 2009), which in turn might be associated with altered luteal $\mathrm{P}_{4}$ secretion. Others have shown that postpartum uterine diseases are associated with low $\mathrm{P}_{4}$ concentrations during the first postpartum luteal phase (Holt et al., 1989; Williams et al., 2007). The delayed resumption of cyclicity associated with postpartum reproductive disorders (Fourichon et al., 2000; Opsomer et al., 2000) might delay the gradual increase in $\mathrm{P}_{4}$ concentrations after parturition. In this respect, cows exhibiting low plasma $\mathrm{P}_{4}$ concentrations in the preceding cycle had a greater concentration of $\mathrm{PGF}_{2 \alpha}$ metabolite (PGFM) following oxytocin challenge (Shaham-Albalancy et al., 2001). In agreement, a CIDR inserted in beef cows lowered plasma PGFM concentrations after oxytocin administration in the subsequent cycle, thus delaying luteolysis (Sakase et al., 2006). These effects are mostly attributed to the decreased number of endometrial oxytocin receptors and the increased number of endometrial $\mathrm{P}_{4}$ receptors induced by $\mathrm{P}_{4}$ (Zollers et al., 1993). Although the effect of reproductive disorders and their association with endometrial function was not examined in the current study, CIDR might decrease $\mathrm{PGF}_{2 \alpha}$ secretion in cows with postpartum reproductive disorders, particularly under summer heat stress conditions, when $\mathrm{P}_{4}$ secretion by the CL is compromised (Wolfenson et al., 2002). The above findings reinforce the observation that a combined effect of environmental heat stress, metabolic stress (low BCS), and pathogenic load (reproductive disorders) results in amplification of the $\mathrm{P}_{4}$ deficiency, leading to high effectiveness of the CIDR treatment.

\section{CONCLUSIONS}

Administration of a CIDR insert on d 5 post-AI to cooled cows during the summer may effectively improve fertility of cows with low BCS and postpartum reproductive disorders. Another recent study (Friedman et al., 2011) indicates that administration of $\mathrm{GnRH}$ and $\mathrm{PGF}_{2 \alpha}$ to induce successive follicular waves is effective in improving summer fertility of subpopulations of cows with high BCS and primiparous cows. In light of the latter and current findings, we suggest that summer reproductive management be based on specific treatments for specific designated subpopulations of cows, rather than seeking a single solution for the whole herd. This approach might lead to better breeding results and increase the margin between treatment cost and benefit gained.

\section{ACKNOWLEDGMENTS}

The authors thank M. Maman and A. Dvir (the Hebrew University, Rehovot, Israel) for their technical assistance, and the teams of Gan and Nitzanim dairies (Kibbutz Negba and Kibbutz Nitzanim, Israel) for their skillful assistance.

\section{REFERENCES}

Beltran, M. P., and J. L. M. Vasconcelos. 2008. Conception rate in Holstein cows treated with $\mathrm{GnRH}$ or hCG on the fifth day post artificial insemination during summer. Arq. Bras. Med. Vet. Zootec. $60: 580-586$

Berman, A., and D. Wolfenson. 1992. Environmental modifications to improve production and fertility. Pages 34-126 in Large Dairy Herd Management. H. H. Van Horn and C. J. Wilcox, ed. American Dairy Science Association, Champaign, IL.

Bicalho, R. C., S. H. Cheong, L. D. Warnick, and C. L. Guard. 2007. Evaluation of progesterone supplementation in a prostaglandin $\mathrm{F}_{2 \alpha}$-based presynchronization protocol before timed insemination. J. Dairy Sci. 90:1193-1200.

Burke, J. M., R. L. De La Sota, C. A. Risco, C. R. Staples, E. J. P. Schmitt, and W. W. Thatcher. 1996. Evaluation of timed insemination using a gonadotropin-releasing hormone agonist in lactating dairy cows. J. Dairy Sci. 79:1385-1393.

Burns, P. D., J. C. Spitzer, and D. M. Henricks. 1997. Effect of dietary energy restriction on follicular development and luteal function in nonlactating beef cows. J. Anim. Sci. 75:1078-1086.

Butler, W. R. 2000. Nutritional interactions with reproductive performance in dairy cattle. Anim. Reprod. Sci. 60-61:449-457.

Diskin, M. G., D. R. Mackey, J. F. Roche, and J. M. Sreenan. 2003. Effects of nutrition and metabolic status on circulating hormones and ovarian follicle development in cattle. Anim. Reprod. Sci. $78: 345-370$.

Fourichon, C., H. Seegers, and X. Malher. 2000. Effect of disease on reproduction in the dairy cow: A meta-analysis. Theriogenology 53:1729-1759.

Franco, M., P. M. Thompson, A. M. Brad, and P. J. Hansen. 2006. Effectiveness of administration of gonadotropin-releasing hormone at days 11, 14 or 15 after anticipated ovulation for increasing fertility of lactating dairy cows and non-lactating heifers. Theriogenology 66:945-954.

Friedman, E., H. Voet, D. Reznikov, I. Dagoni, and Z. Roth. 2011. Induction of successive follicular waves by gonadotropin-releasing hormone and prostaglandin $\mathrm{F}_{2 \alpha}$ to improve fertility of highproducing cows during the summer and autumn. J. Dairy Sci. 94:2393-2402

Green, M. P., M. G. Hunter, and G. E. Mann. 2005. Relationships between maternal hormone secretion and embryo development on day 5 of pregnancy in dairy cows. Anim. Reprod. Sci. 88:179-189.

Holt, L. C., W. D. Whittier, F. C. Gwazdauskas, and W. E. Vinson. 1989. Early postpartum reproductive profiles in Holstein cows with retained placenta and uterine discharges. J. Dairy Sci. 72:533539.

Howell, J. L., J. W. Fuquay, and A. E. Smith. 1994. Corpus luteum growth and function in lactating Holstein cows during spring and summer. J. Dairy Sci. 77:735-739.

Jonsson, N. N., M. R. McGowan, K. McGuigan, T. M. Davison, A. M. Hussain, M. Kafi, and A. Matschoss. 1997. Relationships among calving season, heat load, energy balance and postpartum ovulation of dairy cows in a subtropical environment. Anim. Reprod. Sci. $47: 315-326$.

Jordan, E. R. 2003. Effects of heat stress on reproduction. J. Dairy Sci. 86(E. Suppl.):E104-E114.

Larson, S. F., W. R. Butler, and W. B. Currie. 1997. Reduced fertility associated with low progesterone postbreeding and increased milk urea nitrogen in lactating cows. J. Dairy Sci. 80:1288-1295. 
Lemley, C. O., K. A. Vonnahme, L. R. Tager, K. M. Krause, and M. E. Wilson. 2010. Diet-induced alterations in hepatic progesterone (P-4) catabolic enzyme activity and P-4 clearance rate in lactating dairy cows. J. Endocrinol. 205:233-241.

López-Gatius, F., P. Santolaria, A. Martino, F. Delétang, and F. De Rensis. 2006. The effects of GnRH treatment at the time of AI and 12 days later on reproductive performance of high producing dairy cows during the warm season in northeastern Spain. Theriogenology $65: 820-830$.

Mann, G. E., M. D. Fray, and G. E. Lamming. 2006. Effects of time of progesterone supplementation on embryo development and interferon-[tau] production in the cow. Vet. J. 171:500-503.

Mann, G. E., and G. E. Lamming. 2001. Relationship between maternal endocrine environment, early embryo development and inhibition of the luteolytic mechanism in cows. Reproduction 121:175-180.

Mann, G. E., G. E. Lamming, R. S. Robinson, and D. C. Wathes. 1999. The regulation of interferon-tau production and uterine hormone receptors during early pregnancy. J. Reprod. Fertil. Suppl. 54:317-328.

Mateus, L., L. Lopes da Costa, P. Diniz, and A. J. Ziecik. 2003. Relationship between endotoxin and prostaglandin $\left(\mathrm{PGE}_{2}\right.$ and $\left.\mathrm{PGFM}\right)$ concentrations and ovarian function in dairy cows with puerperal endometritis. Anim. Reprod. Sci. 76:143-154.

Opsomer, G., Y. T. Grohn, J. Hertl, M. Coryn, H. Deluyker, and A. de Kruif. 2000. Risk factors for post partum ovarian dysfunction in high producing dairy cows in Belgium: A field study. Theriogenology $53: 841-857$.

Rivera, R. M., and P. J. Hansen. 2001. Development of cultured bovine embryos after exposure to high temperatures in the physiological range. Reproduction 121:107-115.

Roth, Z., R. Meidan, R. Braw-Tal, and D. Wolfenson. 2000. Immediate and delayed effects of heat stress on follicular development and its association with plasma FSH and inhibin concentration in cows. J. Reprod. Fertil. 120:83-90.

Sakase, M., N. Kawate, C. Nakagawa, M. Fukushima, M. Noda, K. Takeda, S. Ueno, T. Inaba, K. Kida, H. Tamada, and T. Sawada. 2006. Inhibitory effects of CIDR-based ovulation-synchronization protocols on uterine $\mathrm{PGF}_{2 \alpha}$ secretion at the following luteal phase in early postpartum non-cycling beef cows. J. Reprod. Dev. $52: 497-502$

Santos, J. E., W. W. Thatcher, L. Pool, and M. W. Overton. 2001. Effect of human chorionic gonadotropin on luteal function and reproductive performance of high-producing lactating Holstein dairy cows. J. Anim. Sci. 79:2881-2894.

Schmitt, E. J., T. Diaz, C. M. Barros, R. L. de la Sota, M. Drost, E. W. Fredriksson, C. R. Staples, R. Thorner, and W. W. Thatcher. 1996. Differential response of the luteal phase and fertility in cattle following ovulation of the first-wave follicle with human chorionic gonadotropin or an agonist of gonadotropin-releasing hormone. J. Anim. Sci. 74:1074-1083.
Shaham-Albalancy, A., Y. Folman, M. Kaim, M. Rosenberg, and D. Wolfenson. 2001. Delayed effect of low progesterone concentrations on bovine uterine $\mathrm{PGF}_{2 \alpha}$ secretion in the subsequent oestrous cycle. Reproduction 122:643-648.

Shaham-Albalancy, A., M. Rosenberg, Y. Folman, Y. Graber, R. Meidan, and D. Wolfenson. 2000. Two methods of inducing low plasma progesterone concentrations have different effects on dominant follicles in cows. J. Dairy Sci. 83:2771-2778.

Sheldon, I. M., S. B. Price, J. Cronin, R. O. Gilbert, and J. E. Gadsby. 2009. Mechanisms of infertility associated with clinical and subclinical endometritis in high-producing dairy cattle. Reprod. Domest. Anim. 44:1-9.

Spencer, T. E., O. Sandra, and E. Wolf. 2008. Genes involved in conceptus-endometrial interactions in ruminants: Insights from reductionism and thoughts on holistic approaches. Reproduction 135:165-179.

Trout, J. P., L. R. McDowell, and P. J. Hansen. 1998. Characteristics of the estrous cycle and antioxidant status of lactating Holstein cows exposed to heat stress. J. Dairy Sci. 81:1244-1250.

Wildman, E. E., G. M. Jones, P. E. Wagner, R. L. Boman, H. F. Troutt Jr., and T. N. Lesch. 1982. A dairy cow body condition scoring system and its relationship to selected production characteristics. J. Dairy Sci. 65:495-501.

Willard, S., S. Gandy, S. Bowers, K. Graves, A. Elias, and C. Whisnant. 2003. The effects of GnRH administration post-insemination on serum concentrations of progesterone and pregnancy rates in dairy cattle exposed to mild summer heat stress. Theriogenology 59:1799-1810.

Williams, E. J., D. P. Fischer, D. E. Noakes, G. C. W. England, A. Rycroft, H. Dobson, and I. M. Sheldon. 2007. The relationship between uterine pathogen growth density and ovarian function in the postpartum dairy cow. Theriogenology 68:549-559.

Wilson, S. J., R. S. Marion, J. N. Spain, D. E. Spiers, D. H. Keisler, and M. C. Lucy. 1998. Effects of controlled heat stress on ovarian function of dairy cattle. 1. Lactating cows. J. Dairy Sci. 81:21242131.

Wolfenson, D., Z. Roth, and R. Meidan. 2000. Impaired reproduction in heat-stressed cattle: Basic and applied aspects. Anim. Reprod. Sci. 60-61:535-547.

Wolfenson, D., H. Sonego, A. Bloch, A. Shaham-Albalancy, M. Kaim, Y. Folman, and R. Meidan. 2002. Seasonal differences in progesterone production by luteinized bovine thecal and granulosa cells. Domest. Anim. Endocrinol. 22:81-90.

Zollers, W. G. Jr., H. A. Garverick, M. F. Smith, R. J. Moffatt, B. E. Salfen, and R. S. Youngquist. 1993. Concentrations of progesterone and oxytocin receptors in endometrium of postpartum cows expected to have a short or normal oestrous cycle. J. Reprod. Fertil. 97:329-337.

Zulu, V. C., T. Nakao, and Y. Sawamukai. 2002. Insulin-like growth factor-I as a possible hormonal mediator of nutritional regulation of reproduction in cattle. J. Vet. Med. Sci. 64:657-665. 